\title{
Pre-implantational timetable of embryonal development of Myocastor coypus (Coypu)
}

\author{
Antonio E. FeliPe ${ }^{\mathrm{a}}$, Miriam T. Teruel ${ }^{\mathrm{a}, \mathrm{b}}$, Jorge A. CABodevila ${ }^{\mathrm{b}}$, \\ Santiago S. CALLEJAS ${ }^{\mathrm{b} *}$ \\ ${ }^{a}$ Area de Embriología, Facultad de Ciencias Veterinarias, Universidad Nacional del Centro \\ de la Provincia de Buenos Aires, B7000GHG Tandil, Argentina \\ ${ }^{\mathrm{b}}$ Area de Reproducción, Facultad de Ciencias Veterinarias, Universidad Nacional del Centro \\ de la Provincia de Buenos Aires, B7000GHG Tandil, Argentina
}

(Received 10 April 2001; accepted 5 January 2002)

\begin{abstract}
The purpose of the present study was to determine the chronology of the pre-implantation embryonic development in Myocastor coypus (coypu). It was carried out by daily colpocytological examination and controlled mating of 33 females. Oocytes and embryos were obtained by flushing from day 0 to day 10 post-coitus (p.c.). On day 1 p.c., oocytes predominated whereas on day 2 p.c. zygotes were predominant. The cleavage period was from day 3 to day 6 p.c.. Morulae were collected from day 6 to day 9 p.c., whereas blastocysts were collected on days 8 and 9 . From oviduct flushing, the embryos in the zygote stage and up to the morula stage with less than a 30-cell stage were recovered. Embryos in the morula stage with 30 or more cells and up to the growing blastocyst stage were collected from the flushing of hemiuteri.
\end{abstract}

embryo / Myocastor coypus / preimplantational development / timetable

Résumé - Chronologie du développement embryonnaire pré-implantatoire de Myocastor coypus (Coypou). Le but de ce travail est d'établir la chronologie du développement embryonnaire pré-implantatoire de Myocastor coypus (coypou). Après un suivi des cycles œstriens par examen histologique des frottis vaginaux, 33 femelles ont été accouplées. Les ovocytes et les embryons sont examinés dans les lavages du tractus génital entre les jours $0-10$ post-coïtum (p.c.). Au jour 1 p.c., les ovocytes sont majoritaires tandis qu'au jour 2 les zygotes prédominent. La période de segmentation est comprise entre les jours 3-6 p.c. Les morulas sont collectées du jour 6 au jour 9 p.c. et les blastocystes sont observés aux jours 8-9 p.c. Dans les lavages tubaires, les embryons collectés sont entre les stades zygotique et morula inférieure à 30 cellules. Les embryons récoltés dans les lavages utérins sont au stade morula ( 30 cellules ou plus) et au stade blastocyste.

embryon / Myocastor coypus / développement pré-implantatoire / table chronologique

* Correspondence and reprints

E-mail: callejas@vet.unicen.edu.ar 


\section{INTRODUCTION}

Myocastor coypus (coypu) is a rodent found worldwide that is used as a skin species. The coypu inhabits natural environments characterised as continental aquatic environments. Nevertheless, the species has shown great adaptability to different geographical regions and environments. Since its accidental release from breeding farms, it is localised in naturalised populations in England, USA, Eastern European countries, Kenya and Israel [12]. The coypu is an annual polyestrous species, with estrous cycles characterised by a great variability [25, 30]. Iudica and Alberio [25] reported an oestrous cycle ranging between 12 to 49 days, with a mean of $28.9 \pm$ 12.6 days and an oestrus of 2 to 5 days. Myocastor coypus, as other hysthricomorph rodents, has a prolonged gestation, with a mean duration of 132 days $[1,30]$ ranging from 127 to 138 days [40]. In Argentinean breeding farms, the mean number of offspring has been reported by Colantoni [12] to be 3.82 .

Currently, to the best of our knowledge, there is no systematised information on the biology of the development of the coypu, except for some general information when related to other hysthricomorph rodents [33]. The implementation and success of reproductive technologies and, particularly, embryotechnologies require a thorough knowledge of the pre-implantational development [36] and characteristics of the reproductive cycle of the species. The optimum time for obtaining embryos has been studied for many species for which basic knowledge about their pre-implantational development is available. The lack of information available on the development of Myocastor coypus has made it necessary for further knowledge related to the reproductive physiology and embryology of this species to be gained. Hence, the purpose of the present work was to determine the timetable of pre-implantation embryonic development for Myocastor coypus.

\section{MATERIALS AND METHODS}

\subsection{Animals}

Thirty-three virgin and sexually mature females allotted to 6 family nuclei and 1 male were used. All animals were destined to zafra. Females were $8.7 \pm 1.1$ months-old $($ mean $\pm \mathrm{SD})$ and weighed $4.6 \pm 0.6 \mathrm{~kg}$ (mean $\pm \mathrm{SD}$ ). The male was 8 months-old and weighed $5.8 \mathrm{~kg}$. All the family nuclei were constituted of animals from the same genetically pure mutation of Myocastor coypus (Groenland mutation) in order to avoid variances owing to differential fecundity $[7,8]$. The use of a single, reproductively proved sire allowed to control the variations due to the use of different males. Animals were housed in semi-roofed pens with an area of $2 \mathrm{~m}^{2}$ per animal. During the experimental period, animals were fed a pellet feed for the species and water ad libitum.

\subsection{Mating programme}

The mating programme implied a daily colpocytological examination by using standardised routine techniques. Samples for the colpocytological follow-up were collected from all the animals between 11 and 11:30 hours a.m. Disposable plastic Pasteur pipettes, $3 \mathrm{~mL}$, were used to avoid sample contamination and diagnostic mistakes. The observation of vaginal smears was done directly within 5 minutes of sampling and after staining with Harris hematoxilin (Merck) and Shorr dye (standard solution, Biopur).

A controlled mating methodology was used. After the oestrus was established by colpocytology, the female was immediately moved to the male's pen. The embryonic age was determined as days post-coitus (p.c.), establishing as day 0 the day when spermatozoa were identified in the vaginal smear. 


\subsection{Collection and identification of oocytes and embryos}

Flushings for oocyte and embryo collection were carried out on day 0 between 1 and 2 hours p.c. and thereafter from day 1 to 10 p.c. at 24 -hour intervals. Oviducts and uteri were divided into six pairs of segments: the infundibulum, ampulla, cephalic isthmus, middle isthmus, caudal isthmus and hemiuterus. The segments were put in quadrilled-bottom Petri dishes, $35 \mathrm{~mm}$ of diameter, with saline solution at $37^{\circ} \mathrm{C}$. The flushing of segments was carried out under a stereoscopic microscope. Saline solution at $37^{\circ} \mathrm{C}$ was injected into each segment using a 1-mL syringe attached with a blunt needle.

The identification of the embryos in the flushing medium was done in a quadrilledbottom dish, square by square, three times per square. The optical magnification was first $10 \times$ and thereafter $25 \times$ in order to ensure a complete search on the dish surface. The collected oocytes and embryos were studied without processing.

The time of implantation was estimated as the day p.c. at which no embryos were collected from the flushing of females with successful mating and when there was the presence of well developed corpora lutea. The corpora lutea were counted employing a stereoscopic microscope.

\subsection{Classification of specimens}

The classification into the different stages and substages was done considering morphological attributes accordingly with works of Gardner and Lane [16] and Gilbert [17], adopting the following classification: oocytes, zygote, embryos in cleavage, early morulae with less than 30 cells, early morulae with 30 or more cells, compacted morulae, blastocysts with zona pellucida (early, middle and expanded) and blastocysts without zona pellucida (hatched and growing blastocysts).
The criteria used to differentiate the oocytes from the zygote were based on morphological characteristics. The time when the embryos were placed in the flushing medium was considered as the end of embryonic development.

The embryos with abnormal characteristics according to the criteria of Buttler and Biggers [10] and Palma [32], were discarded.

\subsection{Elaboration of the timetable}

A table with the chronology of the preimplantation development was made from the estimation of the embryonic age. In order to do this, all the information obtained from the successive sampling of oocytes and embryos was gathered. Stages classified and identified as identical were grouped and distributed in a gradual series, which included all stages from the two-pronucleate zygote stage to the growing blastocyst.

\subsection{Statistical analysis}

All the values are expressed as means \pm standard deviation of the means. An analysis of variance was used to compare the number of embryos collected per site of the reproductive tract. The level of significance was $P<0.05$ [31].

\section{RESULTS}

A total of 17 oocytes and 153 embryos were collected. The mean number of embryos per female was $6.3 \pm 2.03$, ranging from 1 to 11. The mean number of embryos collected from the right side of the reproductive tract were $3.0 \pm 1.5$, showing statistically non-significant difference $(P>0.05)$ with the mean number of embryos collected from the left-side (3.2 \pm 1.6$)$. The number of corpora lutea found ( $n: 126)$ was lower than the number of oocytes and embryos collected. 
Table I shows the results of the flushing of the reproductive tract of the females. In most of the cases, it was observed that for the same animal the embryos collected were at different developmental stages, but close to each other.

A chronological representation of the development, including all possible stages for the same post-coitus time is presented in Figure 1.

The variation in the observed embryonic stages for a particular female (Tab. I) was also verified for the same p.c. time as shown in Figure 1. The greatest variation in the stages was observed on day 3 p.c., corresponding to three complete cleavage

Table I. Oocytes and embryos collected from Myocastor coypus between 0 and 10 days post-coitus.

\begin{tabular}{|c|c|c|c|c|}
\hline \multirow[t]{2}{*}{ Female } & \multirow[t]{2}{*}{$\begin{array}{l}\text { Days } \\
\text { p.c. }\end{array}$} & \multicolumn{2}{|c|}{$\begin{array}{l}\text { Number of oocytes } \\
\text { and embryos }\end{array}$} & \multirow[t]{2}{*}{ Development stage (number) } \\
\hline & & Right side & Left side & \\
\hline 1 & 0 & - & - & - \\
\hline 2 & 0 & - & - & - \\
\hline 3 & 0 & - & - & - \\
\hline 4 & 1 & 1 & 5 & Oocytes (5), zygotes (1) \\
\hline 5 & 1 & 3 & 2 & Oocytes (4), zygotes (1) \\
\hline 6 & 1 & 2 & 3 & Oocytes (5) \\
\hline 7 & 2 & 3 & 3 & Zygotes (6) \\
\hline 8 & 2 & 3 & 2 & Zygotes (5) \\
\hline 9 & 2 & 3 & 4 & Zygotes (7) \\
\hline 10 & 3 & 2 & 3 & 2 -cells (5) \\
\hline 11 & 3 & 7 & 4 & Oocytes (2), zygotes (3), 2-cells (2), 3-cells (2), 4-cells (2) \\
\hline 12 & 3 & 1 & 7 & 2-cells (3), 3-cells (3), 4-cells (1), 5-cells (1) \\
\hline 13 & 4 & 6 & 3 & 2-cells (9) \\
\hline 14 & 4 & 1 & 5 & 2-cells (6) \\
\hline 15 & 4 & 5 & 3 & Zygotes (1), 2-cells (6), 3-cells (1) \\
\hline 16 & 5 & 4 & - & 8-cells (4) \\
\hline 17 & 5 & 1 & 5 & 2-cells (3), 3-cells (1), 6-cells (2) \\
\hline 18 & 5 & 3 & 5 & 4-cells (3), 6-cells (1), 7-cells (1), 8-cells (2), 9-cells (1) \\
\hline 19 & 6 & 3 & 2 & 7-cells (1), 8-cells (2), 9-cells (1), M-30 cells (1) \\
\hline 20 & 6 & 4 & 3 & 8 cells $(1), 9$ cells $(1)$, M-30 cells $(5)$ \\
\hline 21 & 6 & 1 & - & M-30 cells $(1)$ \\
\hline 22 & 7 & 4 & 5 & $\mathrm{M}+30$ cells $(7), \mathrm{CM}(2)$ \\
\hline 23 & 7 & 4 & 3 & $\mathrm{M}+30$ cells $(5), \mathrm{CM}(2)$ \\
\hline 24 & 7 & 2 & 4 & 6 cells $(1), M-30(5)$ \\
\hline 25 & 8 & 3 & 2 & Early Bt (1), medium Bt (2), expanded Bt (2) \\
\hline 26 & 8 & 2 & 2 & Early Bt (2), medium Bt (1), expanded Bt (1) \\
\hline 27 & 8 & 4 & 5 & $\begin{array}{l}\text { M-30 cells (1), M+30 cells (1), CM (1), early Bt (3), } \\
\text { medium } \mathrm{Bt}(1) \text {, expanded } \mathrm{Bt}(1) \text {, growing Bt (1) }\end{array}$ \\
\hline 28 & 9 & 3 & 1 & Expanded Bt (1), hatched Bt (3) \\
\hline 29 & 9 & 3 & 4 & Medium Bt (1), hatched Bt (2), growing Bt (4) \\
\hline 30 & 9 & 3 & 2 & $\mathrm{CM}$ (2), expanded Bt (2), growing Bt (1) \\
\hline 31 & 0 & - & - & - \\
\hline 32 & 10 & - & - & - \\
\hline 33 & 10 & - & - & - \\
\hline
\end{tabular}

M-30 cells: morula with less than 30 cells; M+30 cells: morula with 30 or more cells; CM: compacted morula; Bt: blastocysts; - not collected. 


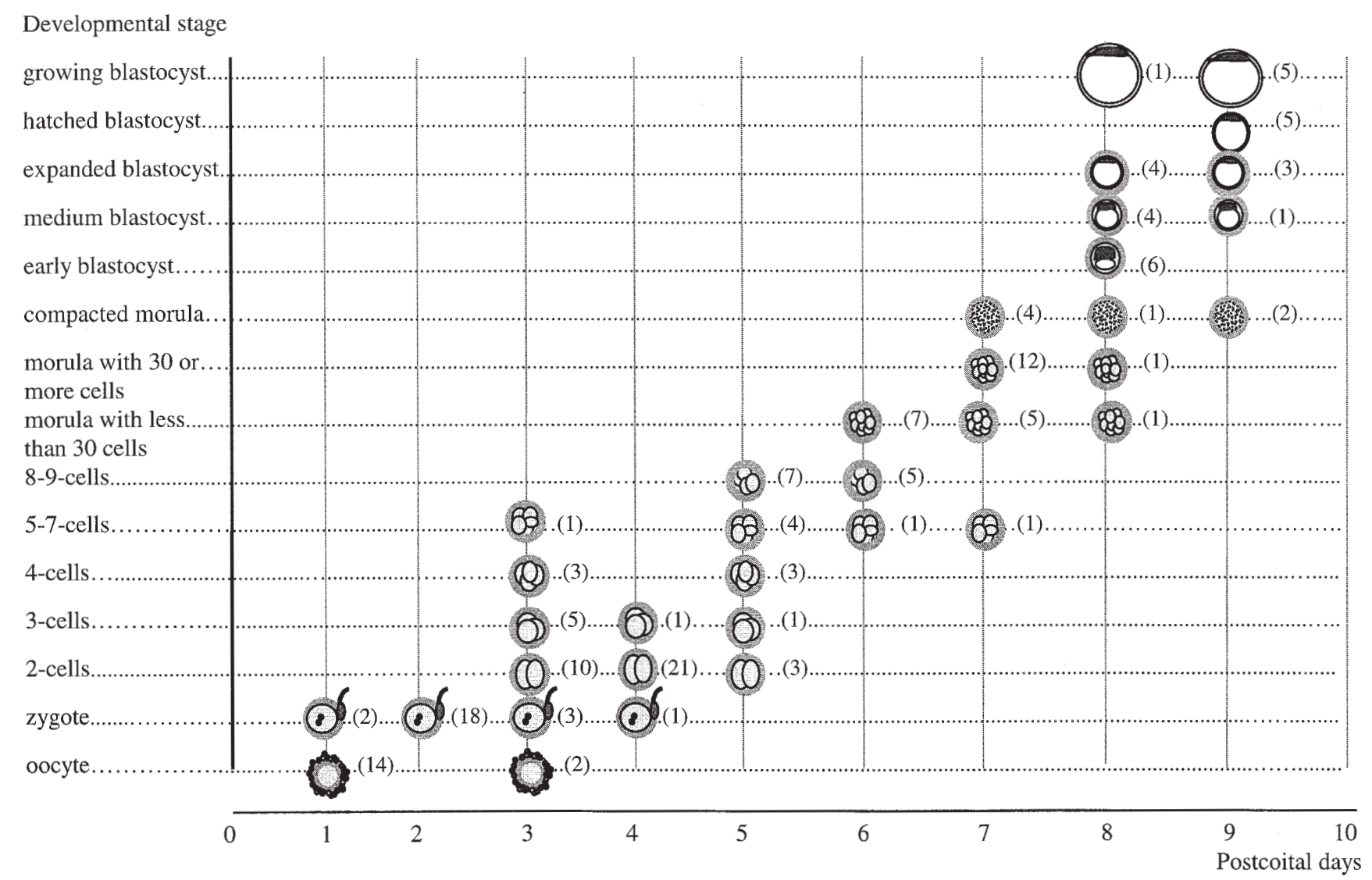


divisions. On the other days, differences were observed in two cleavage divisions. For days 3 and 4 p.c., the embryos of two cells (first complete cleavage) predominated, decreasing the frequency of unicellular specimens as in embryos with second and third completed cleavages. On day 5 p.c., the embryos in the third division predominated, whereas on days 6 and 7 those in the fourth division predominated.

Table II shows the results of the collection of embryos at different stages and substages of development according to the site of collection. In the different portions of the oviduct, the collected embryos were at zygote stages up to the morula with less than 30 cells and, in the hemiuteri, from morula with 30 or more cells to the growing blastocyst. Even though embryos at different stages of development were collected in some sectors, for each sector a determined stage prevailed.

On day 10 p.c., no embryo could be collected (Tab. I and Fig. 1); this day was therefore considered as the probable time of implantation, since the females had successful mating and well-developed corpora lutea.

\section{DISCUSSION}

In the present study, the first precise data about the pre-implantational embryonic development from fecundation to the blastocyst endometrial adhesion in a hysthricomorph rodent, Myocastor coypus, are presented. The pre-implantation embryonic development of Myocastor coypus was estimated to last 10 days, from mating to the moment when adhesion was assumed to take place. This indicates that embryos of coypu stay in the oviduct during a prolonged period (6 days), which implies a later implantation compared with other hysthricomorph rodents [24, 33], except for the viscacha [33]. The relative developmental rates for some species are shown in Table III.

Table II. Distribution of oocytes and embryos of Myocastor coypus per collection site. The values are expressed as percentages.

\begin{tabular}{|c|c|c|c|c|c|c|}
\hline \multirow{2}{*}{$\begin{array}{l}\text { Developmental } \\
\text { stage }\end{array}$} & \multirow[b]{2}{*}{ Infundibulum } & \multirow[b]{2}{*}{ Ampulla } & \multicolumn{2}{|c|}{ Site of collection } & \multirow[b]{2}{*}{$\begin{array}{l}\text { Caudal } \\
\text { isthmus }\end{array}$} & \multirow[b]{2}{*}{ Hemiuterus } \\
\hline & & & $\begin{array}{l}\text { Cephalic } \\
\text { isthmus }\end{array}$ & $\begin{array}{l}\text { Middle } \\
\text { isthmus }\end{array}$ & & \\
\hline Oocyte & 25 & 56.2 & 6.3 & 12.5 & - & - \\
\hline Zygote & - & 20.8 & 62.5 & 16.7 & - & - \\
\hline 2-cells & - & - & 100 & - & - & - \\
\hline 3 -cells & - & - & 57.2 & 42.8 & - & - \\
\hline 4-cells & - & - & 33.3 & 66.7 & - & - \\
\hline 5-7-cells & - & - & - & 50 & 50 & - \\
\hline 8-9-cells & - & - & - & - & 100 & - \\
\hline Morula with less than 30 cells & - & - & - & - & 42.8 & 57.2 \\
\hline Morula with 30 or more cells & - & - & - & - & - & 100 \\
\hline Compacted morula & - & - & - & - & - & 100 \\
\hline Early blastocyst & - & - & - & - & - & 100 \\
\hline Medium blastocyst & - & - & - & - & - & 100 \\
\hline Expanded blastocyst & - & - & - & - & - & 100 \\
\hline Hatched blastocyst & - & - & - & - & - & 100 \\
\hline Growing blastocyst & - & - & - & - & - & 100 \\
\hline
\end{tabular}

- Not observed. 
Table III. Chronology of some developmental events in embryos of different species. The values are expressed as hours post-coitus.

\begin{tabular}{|c|c|c|c|c|c|c|c|}
\hline \multirow[t]{2}{*}{ Order } & \multirow[t]{2}{*}{ Family } & \multirow{2}{*}{$\begin{array}{l}\text { Vulgar } \\
\text { name }\end{array}$} & \multicolumn{5}{|c|}{ Developmental stage/event } \\
\hline & & & $\begin{array}{c}\text { First } \\
\text { cleavage }\end{array}$ & Morulae & $\begin{array}{l}\text { Reaching } \\
\text { to uterus }\end{array}$ & Blastocysts & References \\
\hline \multicolumn{8}{|l|}{ Rodentia } \\
\hline & Myocastoridae & Coypu & 72 & $144-192$ & 168 & 192 & Present study \\
\hline & Chinchillidae & Viscacha & - & - & 144 & 432 & 39 \\
\hline & & Chinchilla & - & 132 & - & - & 33 \\
\hline & Octodontidae & Degu & - & 108 & - & - & 33 \\
\hline & Caviidae & Guinea pig & 24 & 120 & 72 & 96 & 24 \\
\hline & Caviidae & Cuis & - & 60 & - & - & 33 \\
\hline & Muridae & Mouse & $15-17$ & 72 & 72 & 96 & 18 \\
\hline & & Rat & $15-17$ & 96 & $95-100$ & 120 & 20 \\
\hline & & Gerbil & $22-24$ & 96 & - & 120 & 18 \\
\hline Lagomorpha & Leporidae & Rabbit & 24 & $48-72$ & 60 & $74-78$ & 20 \\
\hline
\end{tabular}

- Data not available.

The beginning of the cleavage process has not been established for sure and only a few species. For the guinea pig, a hystricomorph species, Hunter et al. [24] established the beginning of cleavage around 24 hours p.c. In the rat, mouse and golden hamster, cleavage begins 15 to 17 hours p.c. [3]. Based on the above mentioned characteristics for other members of the rodent order, the cleavage process in the coypu would be relatively slow, since it begins 72 hours p.c.

The morula's substages were obtained on days 6 to 8 p.c. In other species (Tab. III), this stage has been observed earlier, between days 2 to 4 p.c. In the coypu, this could be attributed to late processes of ovulation and/or fecundation in relation to the mating time.

The cleavage rate has been linked to genetic influences [38]. For example, the length of cleavage in the mouse varies depending on the strain $[19,28,37]$. In a more recent study, Brownell and Warner [6] demonstrated that the control of embryo cleavage is largely dependent on the genes of the embryo itself and is not a function of the uterine environment.

In all of the mammalian species studied, pre-implantational stages are characterised by a relatively synchronous doubling of cell numbers up to the 8-cell stage [34]. Thereafter the cleavage is asynchronous and this could be due to the development of two different cellular populations: a faster and a slower dividing population. In the coypu, embryos with an odd number of blastomeres were collected at different times. The asynchrony in the division suggests the presence of physiologic differences among blastomeres and, considering the prolonged observation of odd stages in the coypu, these physiologic differences could be considered as being more pronounced than in other species. The differences in the mouse are supposed to take place from the 2-cell stage [26], one of the cells in the 2-cell embryo is the first to divide to the 4-cell stage and its daughters tend to divide ahead of those cells 
derived from its slower partner at all subsequent stages of development up to the blastocyst stage. In the coypu, such a situation could take place from the first division on, given the observation of 3-cell embryos in different females and at different days p.c.

The early asynchronous division observed in the coypu could be an indicator of the zygote polarity as a result both of the polarisation observed in the oocyte cytoplasm [14] as well as of the localisation of the spermatozoon entrance site. In mammals, there is evidence that the polar axis is associated with embryonic, morphogenetic and developmental events from the oocyte formation to implantation. This axis is shown as a gradient of genetic products and organelles that affect the cleavage plains and, lately, it has been shown to be expressed in the phenotype [13, 27].

The duration of the 2-cell stage is also controlled by events associated with the spermatozoon penetration [23]. Ciermerych et al. [11] have shown that the embryonic axes in the mouse are related to the position of the polar body in the 8-cell stage and, hence, to the animal-vegetal axis of the zygote $[15,35]$.

The oviductal transport, which ensures that embryos reach the uterus at the proper time to meet an adequate environment, is the result of the contractility of the reproductive tract $[2,4,29]$, the ciliary movement, the circulation of liquids in the oviduct, the physiological state of the uterotubaric and the ampulle-isthmic joints [20]. A rapid oviductal transport is characteristic of all euteric mammals: it usually takes from 2 to 4 days [18]. The long duration of the transport and the low speed of cleavage suggest the existence of a crosswalk between the embryo and the nervous control of fallopian tube motility. In the case of the uterotubaric joint activity, in rodents and rabbits, a functional occlusion 2-3 days after ovulation has been postulated [21, 22]; it is likely that this occlusion in the coypu could last longer.
The time of reaching the uterus was estimated for the coypu to be on day 7 p.c. (168 hours p.c.), with the early morulae being the more numerous developmental stages. This is similar to the passage from the oviduct to the uterus in other species that takes place with embryos in the advanced cleavage or in the morula stage $[5,9,21]$. The guinea pig and the viscacha are two hystricomorph species for which the stage and time that embryos reach the uterus have been established. Embryos of the former reach the uterus with 8 or more cells [24]. Viscacha's embryos reach the uterus in the 4-cell stage [39]. Despite the late cleavage observed in the coypu, the embryos reach the uterus in a more advanced stage, which is different from other hystricomorphs.

In the present study, an important variation in the developmental stages in a particular animal and in the same p.c. time was observed. This phenomenon was expected since the age of the specimen in development cannot be determined with certainty even when the temporal relations among oestrus, ovulation and the time of successful mating can be established with some degree of exactitude. Hunter et al. [24] observed a great variation in the stages on the same day p.c.; however, to what extent such a variation can be attributed to intrinsically different rates of development between eggs, lack of synchrony of ovulation, or a range in the timing of sperm penetration is unknown. On the contrary, a prolonged process of multiple ovulation and, consequently, oocytes liberated at different times, determining different fecundation times could also contribute to the variation observed in the coypu. It is also possible that the embryos' development, if they were fertilised at the same time, would be non-synchronous [17]. However, although a large variation exists in the developmental rates, especially in the earlier stages, the examination of a great amount of material generally reveals the mean stage of development at any time during the gestation. 
The number of species collected was greater than the copora lutea counted. This fact, probably a consequence of the inability to precisely determine the number of copora lutea, made the determination of the collection rate difficult.

Despite the variation observed, the developmental timetable of Myocastor coypus presented a similar pattern to that of other mammalian species, which encourages performing further comparative studies and makes embryotechnology available.

\section{REFERENCES}

[1] Actis J.J., Cacciamani M.A., Vuegen C., Informe sobre la nutria de criadero en la Argentina, Bol Divulg. Téc. 78 (1989) 1-28.

[2] Aref O.I., Hafez E.S.E., Utero-oviductal motility with emphasis on ova transport, Obstet. Gynecol. Surv. 28 (1973) 679-703.

[3] Bavister B.D., A consistently successful procedure for in vitro fertilization of golden hamster eggs, Gamete Res. 23 (1989) 139-158.

[4] Bodkhe R.R., Harper M.J., Changes in the amount of adrenergic neurotransmitter in the genital tract of untreated rabbits, and rabbits given reserpine or promiazid during the time of egg transport, Biol. Reprod. 6 (1972) 288-299.

[5] Boling J.F., Blandau R.J., Egg transport through the ampullae of the oviducts of rabbits unde various experimental conditions, Biol. Reprod. 4 (1971) 174-184.

[6] Brownell M.S., Warner C.M., Ped gene expression by embryos cultured in vitro, Biol. Reprod. 39 (1988) 806-811.

[7] Bura M., Studiu asupra indicelui de fecunditate la nutrie (Myocastor coypus Molina), Lucrari Stiin. Zootech. 26 (1992) 141-145.

[8] Bura M., Studiu asupra ratei conceptiei la femele primipare si lutipare de nutrie (Myocastor coypus Molina), Lucrari Stiin. Zootech. 26 (1992) 147-151.

[9] Burki K., Experimental Embryology of the Mouse, Krager, New York, 1986.

[10] Butler J.E., Biggers J.D., Assessing the viability of preimplantation embryos in vitro, Theriogenology 32 (1989) 115-126.

[11] Ciermerych M.A., Mesnard D., Zernicka-Goetz M., Animal and vegetal poles of the mouse egg predict the polarity of the embryonic axis, yet are nonessential for development, Development 127 (2000) 3467-3474.

[12] Colantoni L.O., Ecología poblacional de la nutria (Myocastor coypus) en la Provincia de Buenos Aires, Rev. Fauna y Flora Silvestres 1 (1993) $1-25$.
[13] Edwards R.G., The role of embryonic polarities in preimplantation growth and implantation of mammalian embryos, Hum. Reprod. 15 (2000) 1-8.

[14] Felipe A., Teruel M., Callejas S., Cabodevila S., Description of the characteristics of oocytes and zygotes of coypu (Myocastor coypus), Rev. Chil. Anat. 19 (2001) 161-165.

[15] Gardner R.L., Specification of embryonic axes begins before cleavage in normal mouse development, Development 128 (2001) 839-847.

[16] Gardner R.L., Lane M., Amino acids and ammonium regulate mouse embryo development in culture, Biol. Reprod. 48 (1993) 377-385.

[17] Gilbert S.F., Developmental Biology, SinauerSunderland, Massachusetts, 1994.

[18] Hafez E.S.E., Transporte y supervivencia de los gametos, in: Hafez E.S.E. (Ed.), Reproducción e inseminación artificial en animales, Interamericana-McGraw-Hill, México, pp. 182-204.

[19] Harlow G.M., Quinn P., Development of preimplantation mouse embryo in vitro and in vivo, Aust. J. Biol. Sci. 35 (1982) 187-193.

[20] Harper M.J.K., Sperm and egg transport, in: Austin C.R., Short R.V. (Eds.), Reproduction in mammals. I. Germ cells and fertilization, Cambridge University Press, Cambridge, 1982, pp. 102-127.

[21] Harper M.J.K., Gamete and zygote transport, in: Knobil E., Neill J. (Eds.), The Physiology of Reproduction, Raven Press, New York, 1988 , pp. 103-133.

[22] Hodgson B.J., Post-ovulatory changes in the water content and inulin space of the rabbit oviduct, J. Reprod. Fertil. 53 (1978) 349-351.

[23] Howlett S.K., Bolton V.N., Sequence and regulation of morphological and molecular events during the first cell cycle of mouse embryogenesis, J. Embryol. Exp. Morphol. 87 (1985) 175-206.

[24] Hunter R.R.F., Hunt D.M., Chang M.C., Temporal and cytological aspects of fertilization and early development in the guinea pig, Cavia porcellus, Anat. Rec. 165 (1969) 411-429.

[25] Iudica C.E., Alberio R.H., Preliminary study of the sexual cycle of the South-American nutria (Myocastor coypus) by the method of exfoliative colpocytology, Scientifur 19 (1995) 33-42.

[26] Kelly S.J., Mulnard J.G., Graham C.F., Cell division and cell allocation in early mouse development, J. Embryol. Exp. Morphol. 48 (1978) 37-51.

[27] Latham K.E., Schultz R.M., Embryonic genome activation, Front. Biosci. 6 (2001) 748-759.

[28] Molls M., Zamboglou N., Streffer C., A comparison of the cell kinetics of preimplantational mouse embryos from two different strains, Cell Tissue Kinet. 16 (1983) 277-283. 
[29] Moore G.D., Croxatto H.B., Synthetic microspheres transferred to the rat oviduct on day 1 of pregnancy mimic the transport of native ova, J. Reprod. Fertil. 82 (1988) 735-742.

[30] Newson R., Reproduction in the feral coypu (Myocastor coypus), in: Rowlands I. (Ed.), Comparative Biology of Reproduction in Mammals, Cambridge Univ. Press, Cambridge, 1966, pp. 323-334.

[31] Norman G.R., Streiner D.L., Bioestadística, Mosby-Doyma Libros, Madrid, 1996.

[32] Palma G.A., Evaluación morfológica de los embriones, in: Palma, G.A., Brem G. (Eds.), Transferencia de Embriones y Biotecnología de la Reproducción en la Especie Bovina, Hemisferio Sur, Buenos Aires, 1993, pp. 129-142.

[33] Roberts C.M., Perry J.S., Hystricomorph embryology, Symp. Zool. Soc. Lond. 34 (1974) 333-360.

[34] Sakkas D., Vassalli J.D., The preimplantation mammalian embryo, in: Campana A., Dreifuss J.J., Sizonenko P., Vassalli J.D., Villar J. (Eds.), Reproductive Health, Ares-Serono Symposia
Series - Frontiers in Endocrinology, Vol. 2, Ares Serono Symposia Publications, Rome, 1993, pp. 43-54.

[35] Scott L.A., Oocyte and embryo polarity, Semin. Reprod. Med. 18 (2000) 171-183.

[36] Seidel G.E., Embryo transfer: the next 100 years, Theriogenology 35 (1991) 171-180.

[37] Streffer C., van Beuningen D., Molls M. Zamboglou N., Shulz J., Kinetics of cell proliferation in the preimplantational mouse embryo in vivo and in vitro, Cell Tissue Kinet. 13 (1980) 135-143.

[38] Warner C.M., Gollnick S.O., Godbard S.B. Linkage of the preimplantational-embryo-development (Ped) gene to the mouse major histocompatibility complex $(\mathrm{MCH})$, Biol. Reprod. 36 (1987) 606-610.

[39] Weir B.J., The reproductive organs of the plains viscacha, Lagostomus maximus, J. Reprod. Fertil. 25 (1971) 365-373.

[40] Weir B.J., Reproductive characteristics of hystricomorph rodents, Symp. Zool. Soc. Lond. 34 (1974) 265-301. 